\title{
ИЗУЧЕНИЕ ПРОБЛЕМ ХИРУРГИЧЕСКОЙ СТОМАТОЛОГИИ С РАЗРАБОТКОЙ МЕТОДОВ ДИАГНОСТИКИ И ЛЕЧЕНИЯ ЗАБОЛЕВАНИЙ ЧЕЛЮСТНО-ЛИЦЕВОЙ ОБЛАСТИ
}

\section{STUDY OF THE PROBLEMS OF SURGICAL DENTISTRY WITH THE DEVELOPMENT OF METHODS FOR DIAGNOSTICS AND TREATMENT OF DISEASES OF THE MAXILLOFACIAL REGION}

N. Kamneva

Summary. The results of the study, the study of the problems of surgical dentistry with the development of methods for the diagnosis and treatment of diseases of the maxillofacial region, are discussed. G.R. Derzhavin, Tambov. for the period from 2019 to 2021 based on the data obtained in the course of a dental study, the study of the study of the problems of surgical dentistry with the development of methods for the diagnosis and treatment of diseases of the maxillofacial region lies in the fact that the practical significance of the study lies in the fact that its theoretical provisions and the empirical results obtained can be used by dentists for further practice of surgical dentistry. The relevance of the research study of the problems of surgical dentistry with the development of methods for the diagnosis and treatment of diseases of the maxillofacial region, are studied on the basis of the medical institute T.G.U. named after G.R. Derzhavin in modern society is a very important study. Thus, many aspects of the study of dentistry have found their place in the dental problematics, revealing a private and special research study of the problems of surgical dentistry with the development of methods for the diagnosis and treatment of diseases of the maxillofacial region. It can be concluded that the study of the problems of surgical dentistry with the development of methods for the diagnosis and treatment of diseases of the maxillofacial region, for a long time the research methods in their full meaning have not been studied.

Keywords: study of the problems of surgical dentistry with the development of methods for the diagnosis and treatment of diseases of the maxillofacial region. и зучение проблем хирургической стоматологии с разработкой методов диагностики и лечения заболеваний челюстно-лицевой области, они характеризуются многообразием клинических форм и, в то же время, схожестью некоторых симптомов, кроме того, клинические проявления большей части изучение проблем хирургической стоматологии с раз-
Камнева Нина Анатольевна

Врач-стоматолог, к.псх.н., дочент, Тамбовский государственный университет им. Г.Р. Державина,

2. Тамбов

ni_kamneva@mail.ru

Аннотация. 0бсуждаются результаты исследования изучение проблем хирургической стоматологии с разработкой методов диагностики и лечения заболеваний челюстно-лицевой области, в опытно-экспериментальное исследование проводилось на кафедры стоматологии Тамбовского государственного университета им. Г.Р. Державина, г. Тамбова за период с 2019 по 2021 гг. на основании данных, полученных в ходе стоматологического исследования изучение проблем хирургической стоматологии с разработкой методов диагностики и лечения заболеваний челюстно-лицевой области заключается в том, что практическая значимость исследования заключается, что его теоретические положения и полученные эмпирические результаты могут использоваться врачами - стоматологами для дальнейшей практике хирургической стоматологии.

Актуальность исследования изучение проблем хирургической стоматологии с разработкой методов диагностики и лечения заболеваний челюстно-лицевой области, изучаются на базе медицинского института Т.Г.У. им Г.Р. Державина в современном обществе очень важное исследование.

Таким образом, многие аспекты исследования стоматологии нашли свое место в стоматологической проблематики, раскрывая частное и особенное исследования изучение проблем хирургической стоматологии с разработкой методов диагностики и лечения заболеваний челюстно-лицевой области.

Можно сделать вывод о исследования изучение проблем хирургической стоматологии с разработкой методов диагностики и лечения заболеваний челюстно-лицевой области, долгое время не были изучены методы исследования в полном его значении.

Ключевые слова: изучение проблем хирургической стоматологии с разработкой методов диагностики и лечения заболеваний челюстно-лицевой области.

работкой методов диагностики и лечения заболеваний челюстно-лицевой области, затрудняет их дифференциальную диагностику.

Рассмотрим историю развитие практической, научной и учебной основ хирургической стоматологии, изучение проблем хирургической стоматологии с раз- 
Таблица 1

\begin{tabular}{|c|c|c|}
\hline $\begin{array}{l}\text { № } \\
n / \Pi\end{array}$ & Название шкалы & Интерпретация \\
\hline 1 & $\begin{array}{l}\text { Основоположниками хирургической } \\
\text { стоматологии в СССР были московский } \\
\text { стоматолог А.И. Евдокимов }\end{array}$ & $\begin{array}{l}\text { положивший начало клинико-анатомическому направлению исследований } \\
\text { в этом разделе, и челюстно-лицевые хирурги }\end{array}$ \\
\hline 2 & $\begin{array}{l}\text { А.Э. Рауэр (Москва) и А.А. Лимберг } \\
\text { (Ленинград), а также московские хирурги } \\
\text { Н.М. Михельсон и Ф.М. Хитров }\end{array}$ & положивший начало пластической хирургии \\
\hline 3 & Д.А. Энтин ленинградский стоматолог & положивший начало военной челюстно-лицевой хирургии \\
\hline 4 & $\begin{array}{l}\text { Профессор Г.А. Васильев, заведующий } \\
\text { кафедрой пропедевтики хирургической } \\
\text { стоматологии ММСИ им. Н.А. Семашко } \\
\text { (1955-1972) }\end{array}$ & $\begin{array}{l}\text { изучая причины одонтогенных воспалительных заболеваний } \\
\text { верхнечелюстной пазухи, разработал патогистологическую характеристику } \\
\text { одонтогенных гайморитов, для лечения которых было предложено } \\
\text { использование протеолитических ферментов, закрытие перфораций дна } \\
\text { гайморовой полости и др }\end{array}$ \\
\hline 6 & Н.М. Михельсона & $\begin{array}{l}\text { впервые опубликованной «Пластические операции на лице» в 1943-1946 г. } \\
\text { книга, содержавшую результаты научных исследований и описание новых, } \\
\text { оригинальных методов хирургических операций, получивших широкое } \\
\text { применение в практике }\end{array}$ \\
\hline 7 & $\begin{array}{l}\text { Профессор А.И. Евдокимов и (Г.А. Васильев, } \\
\text { В.Ф. Рудько, В.И. Заусаев) }\end{array}$ & $\begin{array}{l}\text { проделали большую работу по восстановительному лечению инвалидов } \\
\text { войны, среди которых значительное место занимали инвалиды, имевшие } \\
\text { тяжелые повреждения зубочелюстной системы }\end{array}$ \\
\hline 8 & $\begin{array}{l}\text { А.И. Евдокимов, А.А. Кьяндский, А.А. Лимберг, } \\
\text { М.В. Мухин, В.Ф. Рудько }\end{array}$ & $\begin{array}{l}\text { ученые обосновали показания к ранней и отсроченной костной пластике } \\
\text { нижней челюсти }\end{array}$ \\
\hline 9 & Ф.М. Хитровым (1903-1986) & $\begin{array}{l}\text { первые операции по устранению врожденных уродств лица были } \\
\text { проведены }\end{array}$ \\
\hline 11 & М.В. Костылев & применение эпидермальных кожных лоскутов \\
\hline 12 & В.И. Кулаженко, М.В. Мухин & положивший начало применение пластмасс в (ч.х.л) \\
\hline 13 & В.М. Месина (1971; ЦНИИ Стоматологии) & $\begin{array}{l}\text { провела исследование «Врожденные расщелины неба (этиология, клиника, } \\
\text { лечение)», в котором как возможный этиологический фактор в генезе } \\
\text { расщелин верхней губы и неба она выделила вирус краснухи и предложила } \\
\text { вакцинацию женщин детородного возраста, разработала методы } \\
\text { диагностики и лечения больныхс расщелинами неба }\end{array}$ \\
\hline 14 & В 1969-1990 гг. профессором В.А. Дунаевским & $\begin{array}{l}\text { изучения патогенеза и совершенствования методов лечения } \\
\text { воспалительных заболеваний челюстно-лицевой области, было } \\
\text { совершенствование методов диагностики, комплексного лечения } \\
\text { и реабилитации больныхс опухолями челюстно-лицевой области }\end{array}$ \\
\hline 15 & Профессор Е.С. Малевич & $\begin{array}{l}\text { научные исследования были направлены на изучение и лечение } \\
\text { доброкачественных и злокачественных новообразований лица и органов } \\
\text { полости рта }\end{array}$ \\
\hline 16 & B.М. Антоневича (1885) & была диссертация «О реплантации и трансплантации зубов» \\
\hline 17 & $\begin{array}{l}\text { Доктор медицины, приват-доцент } \\
\text { Н.Н. Знаменский } \\
(1856-1915)\end{array}$ & одним из первых врачей, кто начал заниматься имплантологией \\
\hline 18 & В.Г. Елисеева и Э.Я. Вареса & $\begin{array}{l}\text { второй этап развития имплантологии в России связан с этими именами } \\
\text { которые, изучая асептическое воспаление от введения в подкожную } \\
\text { соединительную ткань стерильных целлоидиновых трубочек, заметили, } \\
\text { что соединительная ткань, врастая в отверстия трубочек, обрастает ее } \\
\text { по окружности и, превращаясь в рубцовую соединительную ткань, плотно } \\
\text { удерживает трубочку на протяжении жизни животного. Выяснилось, что } \\
\text { соединительная ткань, вросшая в каналы пластмассового имплантата, может } \\
\text { замещаться костной тканью. }\end{array}$ \\
\hline
\end{tabular}


Таблица 1 (продолжение)

\begin{tabular}{|c|c|c|}
\hline $\begin{array}{l}\text { № } \\
\text { п/п }\end{array}$ & Название шкалы & Интерпретация \\
\hline 19 & $\begin{array}{l}\text { С.П. Чепулиса, О.П. Сурова, А.С. Черникиса } \\
(1983 \text { г) }\end{array}$ & $\begin{array}{l}\text { третий этап развития имплантологии } 1983 \text { г. благодаря хорошим } \\
\text { результатам применения титановых имплантатов в Москве была открыта } \\
\text { экспериментальная лаборатория зубной имплантации и протезирования }\end{array}$ \\
\hline 20 & А.И. Матвеевой (1986 г) & $\begin{array}{l}\text { четвертый этап развития имплантологии «О мерах по внедрению в практику } \\
\text { метода ортопедического лечения с использованием имплантатов» }\end{array}$ \\
\hline 21 & $\begin{array}{l}\text { А.С. Черникис, В.А. Воробьев, Б.П. Марков, } \\
\text { В.В. Лось, Э.Г. Амрахов, И.В. Балуда, } \\
\text { С.П. Чепулис, М.З. Миргазизов, Т.Г. Робустова, } \\
\text { В.Н. Олесова, А.А. Кулаков }\end{array}$ & $\begin{array}{l}\text { отечественной имплантологии в 80-90-х гг. XX в. врачи были первыми } \\
\text { разработчиками отечественных имплантатов в форме корня зуба }\end{array}$ \\
\hline 22 & $\begin{array}{l}\text { М.3. Миргазизов с } 1993 \text { г по } 2001 \text { г.- } \\
\text { профессор кафедры клинической } \\
\text { стоматологии и имплантологии Института } \\
\text { повышения квалификации Федерального } \\
\text { управления «Медбио-экстрем» МЗ РФ. }\end{array}$ & $\begin{array}{l}\text { официально была организована секция дентальной имплантации при } \\
\text { Стоматологической ассоциации России }\end{array}$ \\
\hline 23 & А.И. Матвеева, В.Н. Олесова, В.В. Трофимов & $\begin{array}{l}\text { в Москве, Омске и Самаре были защищены первые докторские диссертации, } \\
\text { в том же году было налажено производство имплантатов, которые имеют } \\
\text { винтовые конструкции как для одноэтапной, так и для двухэтапной } \\
\text { операции }\end{array}$ \\
\hline
\end{tabular}

работкой методов диагностики и лечения заболеваний челюстно-лицевой области в России таблицу 1.

Медицина стоматологического периода наблюдалось развитие практической, научной и учебной основ хирургической стоматологии, усовершенствование подготовки специалистов, этому способствовали организация отделений хирургической стоматологии в стоматологических амбулаториях и поликлиниках, открытие специализированных стоматологических стационаров.

Проблема гнойной хирургии челюстно-лицевой области, постоянно находясь в центре внимания стоматологов, требовала и требует знаний микробиологии, фармакологии, физиотерапии и других дисциплин, и решение ее возможно только комплексными методами [5].

Тематика исследований значительно расширялась, появились новые развитие восстановительной хирургии челюстно-лицевой области при врожденных уродствах лица как самостоятельной дисциплины началось в середине 70-х гг [1].

Большой вклад в развитие в 1994 г. в ММСИ была организована кафедра хирургической стоматологии и имплантологии (заведующий профессор С.Ю. Иванов) изучение клинико-теоретических вопросов и полученные положительные результаты при использовании плоских имплантатов нашли место в публикациях В.М. Безрукова, А.И. Матвеевой, А.А. Кулакова, А.И. Ушакова, С.Ю. Иванова [11]. Преимуществом плоских имплантатов является возможность протезировать пациента через 3-4 недели после хирургического вмешательства [8]. Это обстоятельство определило широкое распространение плоских имплантатов в России с 1998 г. стали широко применять плоские отечественные имплантаты «ВНИИМТ», «Конмет» в настоящее время исследования ученых направлены на разработку показаний и противопоказаний к применению имплантов, развитие материаловедения, профилактику осложнений [3].

Хирургическая стоматология - клиническая дисциплина, изучающая заболевания органов полости рта и челюстей, при которых в амбулаторном комплексном лечении основным методом служит оперативное вмешательство [11].

Хирургическая стоматология тесно связана с другими стоматологическими дисциплинами - челюстно-лицевой хирургией, терапией, ортопедией, ортодонтией, стоматологией детского возраста [2]. Эта связь обусловлена анатомо-топографическим и физиологическим единством органов полости рта, челюстно-лицевой области и развивающихся в них патологических процессов [1]. Комплексное лечение стоматологических заболеваний нередко требует участия стоматологов всех специальностей [11].

Проблема совершенствования профилактики и, лечения воспалительных заболеваний является; одной из наиболее актуальных в хирургической стоматологии и челюстно-лицевой хирургии. С другой стороны, увеличивается количество атипично развивающихся, 
вялотекущих воспалительных заболеваний со склонностью к хронизации и рецидивированию, что, несомненно, сопровождается увеличением количества местных и общих осложнений, порой весьма серьезных и требующих сложного, многоэтапного, длительного, дорогостоящего лечения $[4,5,6,9,10]$.

Также, немаловажной особенностью; профилактики и лечения воспалительных процессов полости рта является, отсутствие четких данных о возможных этиологических факторах, способных приводить к развитию воспаления. Прежде всего, следует обратить; внимание, что, большинство пациентов» с хирургической стоматологической патологией имеют сопутствующую патологию, как следствие нарушение иммунной защиты. Нарушения иммунитета может приводить к неэффективности, как профилактического назначения традиционных антибиотиоков, так и быть причиной возникновения инфекционно-воспалительных осложнений $[1,2,3,5,7,8,9,11,12]$.

Результаты исследования изучение проблем хирургической стоматологии с разработкой методов диагностики и лечения заболеваний челюстно-лицевой области в России имеют прикладное значение и могут быть использованы при разработке лекционных курсов.

\section{ЛИТЕРАТУРА}

1. Агапов В.С., Тарасенко С.В., Трухина Г.М., Лакшин А.М. Внутрибольничные инфекции в хирургической стоматологии. М.: Медицина, 2002.255 с.2.

2. Агапов В.С., Смирнов С.Н., Шулаков В.В., Царёв В.Н. Комплексная озонотерапия ограниченного вялотекущего гнойного воспаления мягких тканей челюстно-лицевой области // Стоматология. 2001. — Т80, № 3. - С. 23-27. [4]

3. Инфекции и антимикробная химиотерапия. 2003.- Т. 5, № Г -С. 12-18.

4. Блатун Л.А. Местное медикаментозное № 1.

5. Богдашева Н.И., Фишман Б.Б., Иванов А.С., Абу Кхадир Ессам. Характеристика отдельных маркеров микрофлоры полости рта по данным ПцР диагностики Институт стоматологии. — № 37-Т. 4.-2007. С. 84-85.

6. Ксембаев С.С, Ямашев И.Г. Острые одонтогенные воспалительные заболевания челюстей. М.: «Медпресс-информ», 2006. - 126 с.

7. Робустова Т.Г. Хроническая эндогенная интоксикация при одонтогенных воспалительных заболеваниях // Материалы Х Международной конференции челюстно-лицевых хирургов и стоматологов. СПб., 2005.- С. 155-156.

8. Царев В.Н., Николаева Е.Н. Технологии генодиагностики в отечественной стоматологии // Стоматология. — 2007. — № 5. — C. 82-87.

9. ЦЦарев В.Н., Николаева Е.Н., Носик А.С., Щербо С.Н. Современные методы микробиологической диагностики заболеваний тканей пародонта // Медицинский алфавит. Стоматология. - 2005.-№ 2. - C. 26-29.

10. Царев В.Н., Ушаков Р.В., Давыдова М.М. Лекции поклинической микробиологии для студентов стоматологических факультетов. Иркутск, 1996. 85 с.

11. Яременко А.И. Лечение и профилактика инфекционно-* воспалительных заболеваний челюстно-лицевой области упациентов старших возрастных групп. Автореф.: Дис. . докт. мед. наук. СПб., 2007.- 37 с.

12. Bernhard A.E., Field ICG. A PCR assay to discriminate humanand ruminant feces on the basis of host differences, in Bacteroides.

(c) Камнева Нина Анатольевна ( ni_kamneva@mail.ru ). 